УДК 339.133.017

JEL Classification: D12, M31

\title{
ВИЗНАЧЕННЯ ПРИХИЛЬНОСТІ СПОЖИВАЧІВ ДО НАДАВАЧІВ ПОСЛУГ НА ПРИКЛАДІ АПТЕЧНИХ ЗАКЛАДІВ
}

Дорохова Л.П., канд. фармац. наук, доцент

Національний фармацевтичний університет

Малий В.В., доктор фармац. наук, професор

Національний фармацевтичний університет

Півень О.П., доктор фармац. наук, професор

Національний фармацевтичний університет

Дорохов О.В., канд. техн. наук, доцент

Харківський національний економічний університет імені Семена Кузнеця

Постановка проблеми. У сучасних умовах практично кожна комерційна організація чи підприємство, що працює на ринках роздрібних продажів, послуг, сервісів, спрямованих на обслуговування населення, змушена використовувати принципи глобальної клієнтоорієнтованості. При цьому відповідні складові маркетингу, побудовані на емоціях, дають можливість зміцнити лояльність вже існуючих покупців і завоювати нових. Це, зокрема, стосується й фармацевтичного обслуговування населення. Для досягнення аптеками ефективних бізнес-результатів необхідним $\epsilon$ моделювання та управління враженнями клієнта, врахування вимог сегментів споживачів, що дозволяє залучити клієнтів, поліпшити становище аптеки в умовах конкуренції.

Аналіз останніх наукових досліджень i публікацій. Питання прихильності клієнтів до надавачів послуг наразі розглядається в науковій літературі $[1 ; 2]$. Як вказується в [3; 4], споживчий вибір місць обслуговування (магазинів, місць громадського харчування, побутового обслуговування, установ охорони здоров'я, сервісних фірм, спортивно-оздоровчих, розважальних закладів) є динамічним і важко модельованим процесом.

Для кожної сфери соціально-економічного обслуговування населення $\epsilon$ актуальним, бажаним і необхідним виділити, описати, формалізувати відповідні основні критерії і впливаючі фактори такого споживчого вибору з урахуванням специфіки конкретного ринку і сфери діяльності на ньому підприємств, організацій, котрі надають і пропонують відповідні товари та послуги.

Очевидно, що для кожної предметної області існують відповідні основні параметри обслуговування (ціна, асортимент, якість, фізична доступність). Однак остаточний споживчий вибір визначається не тільки ними, а сукупністю інших (менш важливих для споживача, але теж впливаючих на загальний, остаточний вибір) критеріїв, факторів, параметрів, складових обслуговування.

Невирішені складові загальної проблеми. В умовах конкуренції на роздрібному фармацевтичному ринку виникає завдання оцінити потенційно 
можливу схильність різних груп споживачів до певних аптечних закладів. Однак, незважаючи на актуальність, це питання до цього часу не знайшло адекватного, простого та, водночас, розрахунково обгрунтованого рішення, 3 використанням достатнього математичного підгрунтя, комп’ютерної реалізації.

Формулювання цілей статті. Аналіз і моделювання вибору аптек покупцями, зокрема, прихильності різних сегментів потенційних покупців до певного аптечного закладу, що передбачає попереднє сегментування покупців аптек, виділення типів відвідувачів і аналіз особливості їх вимог з одного боку, та рівня і параметрів сервісів, що надають певні аптеки, з іншого.

Виклад основного матеріалу дослідження. Розглядаючи роздрібний ринок лікарських препаратів і товарів медичного призначення, на основі аналізу літератури можна виділити для подальшого детального розгляду основні критерії оцінки й вибору аптеки споживачами, подані в таблиці 1.

Таблиияя 1

\section{Критерії оцінки аптек споживачами}

\begin{tabular}{|c|c|}
\hline Критерій & Пояснення критерію \\
\hline $\begin{array}{l}\text { Повнота асортименту } \\
\text { (К1) }\end{array}$ & $\begin{array}{l}\text { Ширина (кількість } \quad \text { груп } \\
\text { позицій в кожній групі), стійкість (постійна гла наявність в аптеці) }\end{array}$ \\
\hline $\begin{array}{l}\text { Загальний рівень цін } \\
\text { (К2) }\end{array}$ & $\begin{array}{l}\text { Сприйняття відвідувача за особистим досвідом, відгуками } \\
\text { знайомих, соціальних мереж, вивчення сайтів аптек }\end{array}$ \\
\hline $\begin{array}{l}\text { Рівень обслуговування } \\
\text { покупців (сервіс) (К3) }\end{array}$ & $\begin{array}{l}\text { Сервіс в залі, консультанти, послуги (вимірювання тиску, } \\
\text { перевірка зору тощо), інтернет замовлення через сайт }\end{array}$ \\
\hline $\begin{array}{l}\text { Викладка ліків і } \\
\text { медичних товарів (К4) }\end{array}$ & $\begin{array}{l}\text { Доступність відвідувачеві, кількість викладених } \\
\text { наявність цін, відкриття упаковок медичних товарів }\end{array}$ \\
\hline $\begin{array}{l}\text { Пішохідна і транспортна } \\
\text { доступність (К5) }\end{array}$ & $\begin{array}{l}\text { Зручність пішохідного руху, віддаленість від зупинок } \\
\text { громадського транспорту, відстань від метрополітену }\end{array}$ \\
\hline $\begin{array}{l}\text { Автомобільна парковка } \\
\text { (К6) }\end{array}$ & $\begin{array}{l}\text { Можливість під'їзду на автомобілі прямо до входу в аптеку, } \\
\text { короткочасної зупинки, стоянки (безкоштовно, платно) }\end{array}$ \\
\hline $\begin{array}{l}\text { Навколишня територія } \\
\text { (К7) }\end{array}$ & $\begin{array}{l}\text { Стан тротуарів, пішохідних доріжок, зелені насадження } \\
\text { навколо, наявність лавочок для короткочасного відпочинку }\end{array}$ \\
\hline $\begin{array}{l}\text { Зовнішній вигляд аптеки } \\
\text { в цілому (К8) }\end{array}$ & $\begin{array}{l}\text { Стан і враження від будівлі, де розташована аптека, і сусідніх, } \\
\text { емоційне загальне враження від зовнішнього вигляду аптеки }\end{array}$ \\
\hline $\begin{array}{l}\text { a, реклама, } \\
\text { ий стиль (К9) }\end{array}$ & $\begin{array}{l}\text { Дизайн, колірні рішення, видимість на відстані, освітлення } \\
\text { вночі, рекламні монітори }\end{array}$ \\
\hline група (К10) & Двері, поручні, сходи, покриття перед та дах над входом \\
\hline $\begin{array}{l}\text { ності для } \\
\text { К11) }\end{array}$ & $\begin{array}{l}\text { Місце для розміщення велосипедів, дитячих колясок, лавочки } \\
\text { для відпочинку, урни, декоративні вуличні рослини }\end{array}$ \\
\hline $\begin{array}{l}\text { Організація приміщення } \\
\text { (К12) }\end{array}$ & $\begin{array}{l}\text { Камера зберігання, кількість і розташування вікон } \\
\text { обслуговування, вітрини, інше торгове обладнання, супутні } \\
\text { послуги і відділи (оптика, косметика, лікувальне харчування) }\end{array}$ \\
\hline $\begin{array}{l}\text { Стан приміщення } \\
\text { (К13) }\end{array}$ & $\begin{array}{l}\text { Освітлення і стан повітря (вентиляція, кондиціонування), } \\
\text { дизайн і стан конструктивних елементів, ремонт }\end{array}$ \\
\hline $\begin{array}{l}\text { Устаткування і персонал } \\
\text { (К14) }\end{array}$ & Сучасність і стан обладнання, зовнішній вигляд персоналу \\
\hline $\begin{array}{l}\text { Внутрішні зручності для } \\
\text { відвідувачів (К15) }\end{array}$ & $\begin{array}{l}\text { Куточок покупця, місце відпочинку, доступ в інтернет, ігрова } \\
\text { кімната для дитини тощо }\end{array}$ \\
\hline
\end{tabular}

(отримано авторами на основі експертних опитувань відвідувачів аптек) 
Для побудови багатофакторної моделі, яка б показала потенційну схильність різних категорій відвідувачів аптек до певних 3 них, пропонується використовувати математичне обгрунтування і підходи, викладені, зокрема, в [5]. Спочатку необхідно провести сегментацію покупців аптек за обраними, обгрунтованим критеріям. Така сегментація докладно розглядалася в ряді робіт дослідників фармацевтичного ринку [6-8]. Були обгрунтовані різні сегменти споживачів, зокрема: «верхівка суспільства», «консерватори», «традиціоналісти», «робітничий клас», «законодавці мод», «авангард», «соціальні утриманці», «незаможні». Іншими вченими пропонувалося сегментування на такі групи: «рухомі нуждою» (борці за виживання); «рухомі ззовні» (з почуттям приналежності до середнього класу; з прагненням до переваги, досягнення більшого); «рухомі зсередини» (віддають перевагу власному досвіду; соціально свідомі, відповідальні); «інтегровані» (3 комбінацією цінностей, породжуваних мотивацією зовні і зсередини). Існують i інші сегментації [5; 9]. На основі узагальнення цих підходів нами запропоновано i розглянуто сегментування клієнтів аптек, наведене в таблиці 2.

Таблиия 2

\section{Сегментація споживачів}

\begin{tabular}{|c|c|}
\hline Тип & Соціальні, демографічні, фінансові, споживчі характеристики \\
\hline $\begin{array}{l}\text { Малоімуг } \\
(\mathrm{C} 1)\end{array}$ & $\begin{array}{l}\text { езробітні, багатодітні, соціально незахищені, } 3 \text { мінімальними пенсіями. } \\
\text { упують вкрай необхідне. Консервативні. Економлять. Найважливіша ціна. }\end{array}$ \\
\hline & $\begin{array}{l}\text { енсіонери за віком із середніми пенсіями. Купують тільки потрібне. Ціна } \\
\text { жлива. Консервативні. Ірунтовні. Повільні. }\end{array}$ \\
\hline $\begin{array}{l}3 \text { особли } \\
\text { потреба } \\
\text { (C3) }\end{array}$ & $\begin{array}{l}\text { Особи } 3 \text { особливими потребами, тимчасово обмеженими фізичними } \\
\text { можливостями. Важлива легкість доступу. Ощадливі. }\end{array}$ \\
\hline $\begin{array}{l}\text { Молодь } \\
\text { (C4) }\end{array}$ & $\begin{array}{l}\text { гуденти, особи молодого віку малого і середнього достатку. Імпульсивні. } \\
\text { нергійні. Спортивні. Сучасні. Мобільні. Фінансово нестійкі. }\end{array}$ \\
\hline $\begin{array}{l}3 \text { дітьми } \\
\text { (С5) }\end{array}$ & $\begin{array}{l}\text { атьки, інші відвідувачі } 3 \text { маленькими дітьми, дошкільного віку, } 3 \\
\text { олясками. Важливий доступ. Особливі вимоги до сервісу і приміщення. }\end{array}$ \\
\hline $\begin{array}{l}\text { Бюджетни } \\
\text { (C6) }\end{array}$ & $\begin{array}{l}\text { Вчителі, медпрацівники, працівники к культури, службовці бюджетних } \\
\text { установ. Обмежені в коштах. Грамотні. Обізнані. Помірковані. }\end{array}$ \\
\hline $\begin{array}{l}\text { дящі } \\
\text { триємств }\end{array}$ & $\begin{array}{l}\text { Співробітники різних небюджетних організацій (робітники, службовці, } \\
\text { технічний персонал). Ціни для них є досяжні. Традиційні. Чутливі. }\end{array}$ \\
\hline $\begin{array}{l}\text { Середній } \\
\text { клас (С8) }\end{array}$ & $\begin{array}{l}\text { Дрібні підприємці, самозайняті фізичні особи, менеджери початкового } \\
\text { рівня, держслужбовці середнього рівня, військові. Досить забезпечені. } \\
\text { Екологічні. Спортивні. Ціни їм доступні. }\end{array}$ \\
\hline $\begin{array}{l}\text { Забезпечені } \\
\text { (С9) }\end{array}$ & $\begin{array}{l}\text { Підприємці та менеджери середнього рівня, державні службовці високого } \\
\text { рівня, офіцери збройних сил, силових структур. Без проблем фінансів. Ціни } \\
\text { не є перешкодою. Стежать за здоров'ям. Сприймають інновації, рекламу. }\end{array}$ \\
\hline $\begin{array}{l}\text { Успішні } \\
\text { (С10) }\end{array}$ & $\begin{array}{l}\text { Великі підприємці, топ менеджери, керівники державних організацій і } \\
\text { структур, старші офіцери, одержувачі спеціальних пенсій. Не обмежені в } \\
\text { коштах. Амбітні. Підкреслюють власний статус. Споживають лише } \\
\text { найкращі та брендові лікарські препарати світових виробників. }\end{array}$ \\
\hline
\end{tabular}

(узагальнено авторами на основі літературних джерел) 
Пропонований підхід передбачає наявність вхідної інформації у вигляді двох матриць оцінок. Перша містить мінімально припустимі для кожної групи (сегменту) споживачів рівні кожного з критеріїв оцінювання, а друга є оцінкою кожної з розглянутих аптек по кожному з критеріїв. Розглядався розрахунковий приклад для 10 сегментів споживачів, 15 критеріїв обслуговування та 4 аптек.

Вхідні дані (матриця) граничних вимог відвідувачів до параметрів оцінювання (бажаний рівень відповідного параметру для певних сегментів споживачів) представлені в таблиці 3. Оцінювання здійснювалося за шкалою від 1 до 10 балів, де більше значення відповідає вищому рівню вимог.

Таблиия 3

Вимоги споживачів (C) до рівня складових (К) сервісу в аптеці

\begin{tabular}{|c|c|c|c|c|c|c|c|c|c|c|c|c|c|c|c|}
\hline & К1 & К2 & К3 & К4 & К5 & К6 & К7 & К8 & К9 & К10 & К11 & К12 & К13 & К14 & К15 \\
\hline C1 & 4 & 9 & 3 & 3 & 4 & 2 & 3 & 3 & 4 & 3 & 3 & 3 & 3 & 3 & 3 \\
\hline C2 & 5 & 8 & 5 & 4 & 8 & 4 & 8 & 4 & 4 & 8 & 4 & 4 & 4 & 4 & 7 \\
\hline C3 & 5 & 1 & 7 & 4 & 9 & 9 & 8 & 4 & 3 & 9 & 4 & 8 & 4 & 4 & 4 \\
\hline C4 & 6 & 7 & 6 & 6 & 5 & 5 & 5 & 6 & 6 & 4 & 8 & 4 & 5 & 7 & 5 \\
\hline C5 & 6 & 6 & 6 & 5 & 7 & 4 & 6 & 5 & 5 & 6 & 8 & 5 & 5 & 7 & 6 \\
\hline C6 & 8 & 7 & 7 & 7 & 5 & 4 & 4 & 6 & 6 & 5 & 5 & 5 & 5 & 7 & 5 \\
\hline C7 & 7 & 6 & 6 & 6 & 5 & 5 & 4 & 6 & 5 & 5 & 5 & 5 & 5 & 6 & 5 \\
\hline C8 & 8 & 5 & 8 & 7 & 7 & 7 & 4 & 7 & 7 & 5 & 7 & 7 & 7 & 7 & 7 \\
\hline C9 & 9 & 4 & 8 & 5 & 5 & 8 & 3 & 8 & 8 & 7 & 3 & 7 & 8 & 8 & 8 \\
\hline C10 & 9 & 3 & 9 & 4 & 4 & 9 & 3 & 9 & 8 & 7 & 3 & 7 & 8 & 9 & 8 \\
\hline
\end{tabular}

(отримано авторами на основі експертних опитувань відвідувачів аптек)

Нами було розглянуто 4 аптеки в центральній частині м. Харкова, однак ми приводимо лише знеособлені дані щодо них (як для аптек № 1, 2, 3, 4) 3 огляду на питання комерційної репутації, рекламування, іміджу тощо. Для цих аптек вхідна матриця «аптека - критерій оцінювання», що описує рівень аптеки по кожному окремому конкретному параметру, представлена в таблиці 4.

Таблиия 4

Наявний рівень складових (К) сервісу в аптеках (А), що розглянуті

\begin{tabular}{|l|l|l|l|l|l|l|l|l|l|l|l|l|l|l|l|}
\hline & K1 & К2 & К3 & К4 & К5 & К6 & К7 & К8 & К9 & К10 & К11 & К12 & К13 & К14 & К15 \\
\hline A1 & 5 & 4 & 3 & 3 & 6 & 5 & 4 & 3 & 3 & 8 & 3 & 6 & 4 & 5 & 3 \\
\hline A2 & 5 & 6 & 4 & 5 & 6 & 3 & 8 & 5 & 6 & 2 & 3 & 6 & 4 & 5 & 5 \\
\hline A3 & 7 & 7 & 4 & 3 & 8 & 4 & 6 & 7 & 5 & 3 & 3 & 4 & 3 & 4 & 4 \\
\hline A4 & 7 & 8 & 5 & 7 & 3 & 6 & 5 & 3 & 3 & 6 & 3 & 4 & 4 & 5 & 3 \\
\hline
\end{tabular}

(отримано авторами на основі експертних опитувань відвідувачів аптек)

У результаті математичних розрахунків за алгоритмом, обгрунтованим авторами в [10] і реалізованим нами у вигляді комп'ютерної програми, можна отримати потенційно можливу прихильність різних груп споживачів до тієї чи іншої аптеки, що уточнює положення аптек щодо ставлення до них споживачів. Для наведених вхідних даних (матриць) проведені розрахунки в створеній 
комп'ютерній програмі. В результаті отримано матрицю тяжіння «відвідувач аптека» (наведену в таблиці 5), яка зв'язує потенційних клієнтів і аптеки та показує, до яких з аптек схильні звертатися ті чи інші категорії покупців.

Таблиия 5

Прихильність різних сегментів (типів) споживачів (С) до певних аптек (А)

\begin{tabular}{|c|c|c|c|c|}
\hline & A1 & A2 & A3 & A4 \\
\hline $\mathrm{C} 1$ & 4,3 & 5,1 & 5,2 & 5,1 \\
\hline $\mathrm{C} 2$ & 4,5 & 5,0 & $\overline{5,0}$ & 4,9 \\
\hline $\mathrm{C} 3$ & 4,7 & $\overline{4,8}$ & $\overline{4,7}$ & 4,7 \\
\hline $\mathrm{C} 4$ & 4,2 & $\overline{4,9}$ & 4,8 & 4,8 \\
\hline $\mathrm{C} 5$ & 4,3 & $\underline{4,9}$ & 4,8 & 4,7 \\
\hline C6 & 4,3 & 4,9 & 4,9 & 5,0 \\
\hline C7 & 4,3 & 4,8 & 4,9 & 4,9 \\
\hline $\mathrm{C} 8$ & 4,3 & $\underline{4,8}$ & $\underline{4,8}$ & 4,7 \\
\hline C9 & 4,4 & 4,7 & 4,7 & 4,8 \\
\hline C10 & 4,4 & 4,7 & 4,7 & $\overline{4,7}$ \\
\hline
\end{tabular}

(обчислено авторами в спечіально створеній комп'ютерній програмі)

Як видно, «Аптека № 1» не має сегментів клієнтів, які віддають перевагу саме їй. Натомість, «Аптека № 2» має найбільшу схильність з боку категорій «3 особливими потребами», «Молодь», «3 дітьми». Водночас, «Аптека № 3» більше інших приваблива для сегменту «Малоімущі». Нарешті, «Аптека № 4» виявилася найпривабливішою для таких категорій, як «Бюджетники» i «Забезпечені». Інші сегменти (категорії) відвідувачів однаково схильні одночасно до двох («Літні», «Трудящі підприємств»), і навіть трьох аптек («Успішні»). Отримані результати правильно відображають об'єктивно існуючий, 3 особливостями для кожної, загальний інтегральний рівень зручності обслуговування в розглянутих аптеках і відповідне ставлення до них різних груп відвідувачів.

Висновки 3 проведеного дослідження. Таким чином, пропонований підхід, відповідна комп'ютерна програма і розрахунки в ній, дозволяють досить повно і об'єктивно відобразити багатокритеріальні вимоги і критерії оцінки 3 боку різних груп покупців, виявити схильність їх до тих чи інших аптек, засновану на забезпеченні останніми певного рівня цих вимог. Це дає можливість, з одного боку, кожній аптеці визначити коло своїх потенційних покупців і здійснювати цілеспрямовану маркетингову політику, націлену на них, i, 3 іншого боку, встановити слабкі місця, недоліки за окремими критеріями, усунення яких дозволить залучити інші сегменти клієнтів, а також визначити найближчих конкурентів для різних сегментів.

\section{Перелік посилань}

1. Bolos, L., Lagerkvist, C., Rodolfo, M. (2019), Consumer choice and food waste: can nudging help?, Choices: The Magazine of Food, Farm, and Resource Issues, Vol. 34(1), P. 23-39. 
2. Haggag, K., Pope, D., Bryant, K., Bos, M. (2019), Attribution bias in consumer choice, Review of Economic Studies, Vol. 86(5), P. 2136-2183.

3. Huettner, F., Boyacı, T., Akçay, Y. (2019), Consumer choice under limited attention when alternatives have different information costs, Operations Research, Vol. 67(3), P. 671-699.

4. Huseynov, S., Kassas, B., Segovia, M., Palma, M. (2019), Incorporating biometric data in models of consumer choice, Applied Economics, Vol. 51(14), P. 1514-1531.

5. Gurau, C. (2005), Pharmaceutical marketing on the Internet: marketing techniques and customer profile, The Journal of Consumer Marketing, Vol. 22, No. 7, P. 421-439.

6. Kevrekidis, D., Minarikova, D., Markos, A., Malovecka, I., Minarik, P. (2018), Community pharmacy customer segmentation based on factors influencing their selection of pharmacy and over-the-counter medicines, Saudi Pharmaceutical Journal, Vol. 26, Issue 1, P. 33-43.

7. Liu, J., Liao, X., Huang, W., Liao, X. (2019), Market segmentation: A multiple criteria approach combining preference analysis and segmentation decision, Omega, Vol. 83(C), P. 1-13.

8. Schommer, J., Gaither, C. (2014), A segmentation analysis for pharmacists' and patients' views of pharmacists' roles, Res. Social Adm. Pharm., Vol. 10 (3), P. 508-528.

9. Wiedmann, K., Hennigs, N., Pankalla, L., Kassubek, M., Seegebarth, B., Reeh, M. (2010), Online distribution of pharmaceuticals: investigating relations of consumers' value perception, online shopping attitudes and behaviour in a epharmacy context, Journal of Customer Behaviour, Vol. 9, No. 2, P. 175-199.

10. Dorokhov, O., Dorokhova, L. (2009), Multicriterial models of drugs suppliers and manufacturers choice by pharmacies, International Journal of Advanced Statistics and IT\&C for Economics and Life Sciences, Vol. 1, No. 2, P. 128-135.

\section{РЕФЕРАТИ РЕФЕРАТЫ ABSTRACTS}

\section{УДК 339.133.017; JEL Classification: D12, M31}

Дорохова Л.П., Малий В.В., Півень О.П., Дорохов О.В.

ВИЗНАЧЕННЯ ПРИХИЛЬНОСТІ СПОЖИВАЧІВ ДО НАДАВАЧІВ ПОСЛУГ НА ПРИКЛАДІ АПТЕЧНИХ ЗАКЛАДІВ

Mema: аналіз i моделювання вибору аптек покупцями, зокрема, прихильності різних сегментів потенційних покупців до певного аптечного закладу, що передбачає попереднє сегментування покупців аптек, виділення типів відвідувачів і аналіз особливості їх вимог з одного боку, та рівня i параметрів сервісів, що надають певні аптеки, 3 іншого. Методика дослідження: експертні дослідження, сегментація відвідувачів аптечних закладів, комп'ютерне моделювання. Результати дослідження: визначено 
потенційну прихильність різних сегментів покупців до аптечних закладів, яку розраховано на основі суміщення вимог різних груп споживачів до рівня складових обслуговування та можливостей надання бажаного рівня сервісу кожною з розглянутих аптек. Наукова новизна: запропоновано оригінальний підхід та розроблено відповідну комп'ютерну програму і проведено чисельні розрахунки в ній, котрі дозволяють досить повно і об'єктивно відобразити багатокритеріальні вимоги і критерії оцінки з боку різних груп потенційних покупців лікарських засобів та продукції фармацевтичного асортименту i призначення, виявити схильність їх до тих чи інших аптек, що конкурують на роздрібному фармацевтичному ринку, засновану на забезпеченні останніми певного, необхідного споживачам, рівня вимог та умов обслуговування. Практична значущість: надано практичний, простий та достовірний інструментарій, що дозволяє аптечним закладам визначити коло своїх потенційних покупців і здійснювати цілеспрямовану маркетингову політику, націлену на них, i, з іншого боку, встановити слабкі місця, недоліки за окремими критеріями, усунення яких дозволить залучити інші сегменти клієнтів, а також визначити найближчих конкурентів для різних сегментів.

Ключові слова: поведінка споживачів; фармацевтичний маркетинг; фармацевтичне обслуговування; оцінювання аптеки; сприйняття іміджу; прихильність споживачів.

\section{УДК 339.133.017; JEL Classification: D12, M31}

Дорохова Л.П., Малый В.В., Пивень Е.П., Дорохов А.В.

ОПРЕДЕЛЕНИЕ ПРИВЕРЖЕННОСТИ ПОТРЕБИТЕЛЕЙ К ПОСТАВЩИКАМ УСЛУГ НА ПРИМЕРЕ АПТЕЧНЫХ УЧРЕЖДЕНИЙ

Цель: анализ и моделирование выбора аптек покупателями, в частности, приверженности различных сегментов потенциальных покупателей к определенному аптечному учреждению, что предполагает предварительное сегментирование покупателей аптек, выделение типов посетителей и анализ особенностей их требований с одной стороны, и уровня и параметров сервисов, предоставляемых определенными аптеками, с другой. Методика исследования: экспертные исследования, сегментация посетителей аптечных учреждений, компьютерное моделирование. Результаты исследования: определена потенциальная приверженность различных сегментов покупателей к аптечным учреждениям, рассчитанная на основе совмещения требований различных групп потребителей к уровню составляющих обслуживания и возможностей предоставления желаемого уровня сервиса каждой из рассмотренных аптек. Научная новизна: предложен оригинальный подход и разработана соответствующая компьютерная программа, также проведены численные расчеты в ней, которые позволяют достаточно полно и объективно отразить многокритериальные требования и критерии оценки со стороны различных групп потенциальных покупателей лекарственных средств и продукции фармацевтического ассортимента и назначения, выявить склонность 
их к тем или иным аптекам, конкурирующим на розничном фармацевтическом рынке, основанную на обеспечении последними определенного, необходимого потребителям, уровня требований и условий обслуживания. Практическая значимость: предоставлен практичный, простой и достоверный инструментарий, позволяющий аптечным заведениям определить круг своих потенциальных покупателей и осуществлять целенаправленную маркетинговую политику, нацеленную на них, и, с другой стороны, установить слабые места, недостатки по отдельным критериям, устранение которых позволит привлечь другие сегменты клиентов, а также определить ближайших конкурентов для различных сегментов.

Ключевые слова: поведение потребителей; фармацевтический маркетинг; фармацевтическое обслуживание; оценивание аптеки; восприятие имиджа; приверженность потребителей.

\section{UDC 339.133.017; JEL Classification: D12, M31 Dorokhova L.P., Malyi V.V., Piven O.P., Dorokhov O.V. DETERMINATION OF CONSUMER AFFECTION TO SERVICE PROVIDERS ON THE EXAMPLE OF PHARMACIES}

Purpose: analysis and modeling of the choice of pharmacies by buyers, in particular, the commitment of various segments of potential buyers to a particular pharmacy, which involves preliminary segmentation of pharmacy buyers, identifying types of visitors and analyzing the specifics of their requirements on the one hand, and the level and parameters of services provided by certain pharmacies, with other. Methodology of research: expert research, segmentation of pharmacy visitors, computer modeling. Findings: the potential adherence of various segments of buyers to pharmacies was determined, calculated on the basis of combining the requirements of various groups of consumers to the level of service components and the possibilities of providing the desired level of service for each of the reviewed pharmacies. Originality: an original approach was proposed and a corresponding computer program was developed, numerical calculations were also carried out in it, which allow one to fairly fully and objectively reflect the multicriteria requirements and evaluation criteria from various groups of potential buyers of medicines and pharmaceutical products and prescriptions, to reveal their tendency to one or another pharmacies competing in the retail pharmaceutical market, based on the provision of the latter with a certain level of requirements and conditions of service required by consumers. Practical value: a practical, simple and reliable toolkit has been provided that allows pharmacies to determine the circle of their potential buyers and implement targeted marketing policies aimed at them, and, on the other hand, to identify weaknesses, shortcomings by individual criteria, the elimination of which will attract other customer segments, and also identify the closest competitors for different segments.

Key words: consumer behavior; pharmaceutical marketing; pharmaceutical service; pharmacy evaluation; image perception; consumer commitment. 


\section{Відомості про авторів / Сведения об авторах / About the Authors}

Дорохова Людмила Петрівна - кандидат фармацевтичних наук, доцент, Національний фармацевтичний університет, доцент кафедри фармацевтичного менеджменту та маркетингу, м. Харків, Україна; e-mail: liudmyladorokhova@gmail.com; Моб. (050) 910-03-19.

Дорохова Людмила Петровна - кандидат фармацевтических наук, доцент, Национальный фармацевтический университет, доцент кафедры фармацевтического менеджмента и маркетинга, г. Харьков, Украина.

Dorokhova Liudmyla - PhD in Pharmacy, Associate Professor, National University of Pharmacy, Associate Professor of Department of Pharmaceutical Management and Marketing, Kharkiv, Ukraine.

Малий Володимир Валентинович - доктор фармацевтичних наук, професор, Національний фармацевтичний університет, професор, завідувач кафедри фармацевтичного менеджменту та маркетингу, м. Харків, Україна; еmail: malyi.vladimyr@gmail.com; Моб. (050) 841-55-77.

Малый Владимир Валентинович - доктор фармацевтических наук, профессор, Национальный фармацевтический университет, профессор, заведующий кафедры фармацевтического менеджмента и маркетинга, г. Харьков, Украина.

Malyi Volodymyr - D.Sc. in Pharmacy, Professor, National University of Pharmacy, Professor, Head of Department of Pharmaceutical Management and Marketing, Kharkiv, Ukraine.

Півень Олена Петрівна - доктор фармацевтичних наук, професор, Національний фармацевтичний університет, професор кафедри фармацевтичного менеджменту та маркетингу, м. Харків, Україна; e-mail: piven_elena_pt@ukr.net; Моб. (068) 892-38-81.

Пивень Елена Петровна - доктор фармацевтических наук, профессор, Национальный фармацевтический университет, профессор кафедры фармацевтического менеджмента и маркетинга, г. Харьков, Украина

Piven Olena - D.Sc. in Pharmacy, Professor, National University of Pharmacy, Professor of Department of Pharmaceutical Management and Marketing, Kharkiv, Ukraine.

Дорохов Олександр Васильович - кандидат технічних наук, доцент, Харківський національний економічний університет імені Семена Кузнеця, доцент кафедри інформаційних систем, м. Харків, Україна; e-mail: aleks.dorokhov@meta.ua; Моб. (095) 409-39-40.

Дорохов Александр Васильевич - кандидат технических наук, доцент, Харьковский национальный экономический университет имени Семена Кузнеца, доцент кафедры информационных систем, г. Харьков, Украина

Dorokhov Oleksandr - PhD in Technical Sciences, Associate Professor, Kharkiv National University of Economics named after Semyon Kuznets, Associate Professor of Department of Information Systems, Kharkiv, Ukraine. 